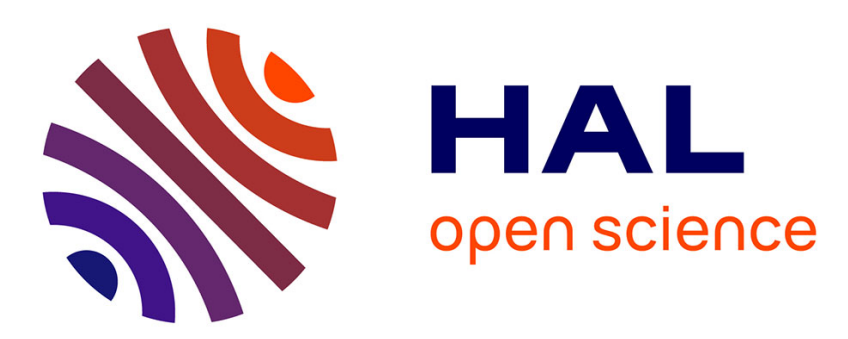

\title{
Organisational and spatial determinants of the multi-unit firm: evidence from the French industry
}

Danielle Galliano, Nicolas Soulié

\section{To cite this version:}

Danielle Galliano, Nicolas Soulié. Organisational and spatial determinants of the multiunit firm: evidence from the French industry. Regional Studies, 2012, 46 (7), pp.907-926. 10.1080/00343404.2010.534777 . hal-00670739

\section{HAL Id: hal-00670739 \\ https://hal.science/hal-00670739}

Submitted on 16 Feb 2012

HAL is a multi-disciplinary open access archive for the deposit and dissemination of scientific research documents, whether they are published or not. The documents may come from teaching and research institutions in France or abroad, or from public or private research centers.
L'archive ouverte pluridisciplinaire HAL, est destinée au dépôt et à la diffusion de documents scientifiques de niveau recherche, publiés ou non, émanant des établissements d'enseignement et de recherche français ou étrangers, des laboratoires publics ou privés. 


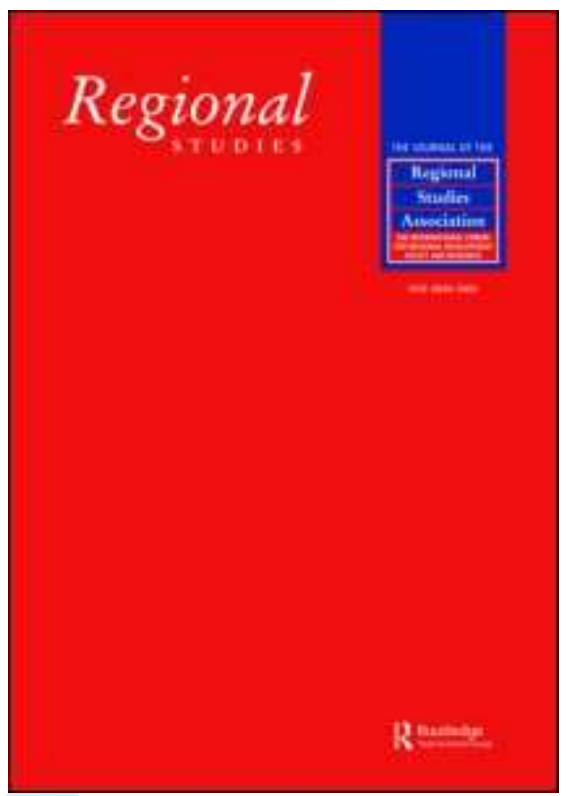

\section{Organisational and spatial determinants of the multi-unit firm: \\ Evidence from the French industry}

\begin{tabular}{|r|l|}
\hline Journal: & Regional Studies \\
\hline Manuscript ID: & CRES-2009-0187.R2 \\
\hline Manuscript Type: & Main Section \\
\hline JEL codes: & $\begin{array}{l}\text { L2 - Firm Objectives, Organization, and Behavior }<\mathrm{L}-\text { Industrial } \\
\text { Organization, L6 - Industry Studies: Manufacturing }<\mathrm{L}-\text { Industrial } \\
\text { Economic Development }<\text { O - Economic Development, } \\
\text { Technological Change, and Growth, R3 - Production Analysis and } \\
\text { Firm Location }<\text { R - Urban, Rural, and Regional Economics }\end{array}$ \\
\hline \hline Keywords: & Multi-unit firm, Organisation of firm, French industry \\
\hline
\end{tabular}

\section{SCHOLARONE" \\ Manuscripts}


Organisational and spatial determinants of the multi-unit firm:

Evidence from the French industry

\author{
Danielle GALLIANO \\ INRA - UMR 1248 AGIR \\ BP 52627, F-31326 Castanet Tolosan Cedex, France \\ Email: galliano@toulouse.inra.fr \\ Nicolas SOULIÉ \\ ADIS - Université Paris-Sud 11 \\ 54, boulevard Desgranges, F-92331 Sceaux, France \\ Email : nicolas.soulie@u-psud.fr
}

(Received June 2009 : in revised form October 2010) 


\begin{abstract}
:
This article aims to analyse the factors (internal characteristics, spatial and industrial environments) that determine the existence of multi-unit firms and the intensity of their organisational fragmentation at a national scale. The empirical models are based on individual data on all French industrial firms, collected by the French National Institute of Statistics. The results show the importance of internal characteristics (scale economies, specific assets as R\&D and advertising, skill level...) in organisational choice. They also highlight the major role played by multi-location and by the spatial profile of the firms on the intensity of their fragmentation.
\end{abstract}

Keywords: Multi-unit firm, spatial organisation of the firm, French industry. JEL Codes: L2, L6, R3, O18.

French title : Les déterminants organisationnels et spatiaux de la firme multi-établissements : une étude des firmes industrielles françaises

French abstract :

Cet article a pour objectif d'analyser les facteurs (caractéristiques internes, environnements spatial et industriel) qui déterminent l'existence des firmes multi-établissements et l'intensité de leur fragmentation organisationnelle à une échelle nationale. Les modélisations empiriques sont basées sur l'exploitation de données individuelles fournies par l'Institut National de la Statistique et des Etudes Economiques (INSEE). Les résultats montrent l'importance des caractéristiques internes (économies d'échelle, actifs intangibles tels que la R\&D ou la 
publicité, qualification des salariés, etc.) dans les choix organisationnels. Ils soulignent également le rôle majeur joué par la multi-localisation et le profil spatial des firmes sur l'intensité de leur fragmentation.

French keywords : Firme multi-établissements, organisation spatiale de la firme, industrie française. 
For many historians and economists, the development of multi-unit firms has been one of the most important elements in the organisational changes that have occurred in the industrial world in the last century (CHANDLER, 1977, p. 1-4; DICKEN, 1976; SCOTT, 1986). These firms differ from spatially integrated enterprises in that they possess several plants that are geographically separated but that operate under the control of one unique head-office. While international firms are central actors in international economics, very few authors have studied the role of multi-unit firms in a national context. ${ }^{1}$ Yet, the latter have now become a crucial actor in our national and regional economies. These firms now represent over one quarter of all industrial firms and employ 60 to $70 \%$ of all workers in France and in the U.S.A. (KIM, 1999).

A multi-unit enterprise is a firm that has the ability to organise and segment its activities into several sites which raises the question of the more complex relationship between firms and territory. Multi-unit firm is defined as having a legal personality and comprising at least two geographically separate plants. ${ }^{2}$ Unlike an integrated, single-unit enterprise, which is defined as having one unique location, the multi-unit firm is characterised by a more complex productive and spatial organisation that enables the firm to benefit from various types of externalities according to the location of its plants at a national scale (OTA and FUJITA, 1993; CHEVASSUS-LOZZA and GALLIANO, 2003). This capacity for multi-location and for a functional and productive segmentation of activities can lead to an increasing functional and sectoral division of productive spaces. Identifying the organisation and location logics of this economic actor can be important in terms of territorial policies as MUFs can be a driving force behind the spatial differentiation of activities and jobs. 
Thus, this article aims to investigate the factors that are conducive to a multi-unit organisation and that influence the intensity of their organisational fragmentation. In this context, the first goal is to study the characteristics that distinguish single from multi-unit firms. We aim to expand the study of large MUFs and highlight the characteristics (internal, strategies and external coordination modes) that differentiate the two forms of organisation (single vs multiunit firms). Secondly, we aim to highlight the factors that have an influence on the degree of fragmentation of a multi-unit firm and to analyse the associated forms of multi-location. Whereas the recent literature has concentrated on analysing firms' location choices at microeconomic level (at the level of new plant, head-office or FDI), our aim here is to study the global spatial organisation of firms (head-quarter and plants, spatial profiles) and its relation to organisational entropy. These different steps will help us to better understand how these dominant actors in the French productive system coherently articulate organisational considerations and spatial logics.

After describing the organisational and spatial factors which, according to the literature, influence the decision to spatially split up the firm and the intensity of this fragmentation, the aim is to test these hypotheses in a two stage HECKMAN (1979) estimation procedure framework. This method allows us to deal with selection bias, by taking into account the determinants of the forms of organisation (fragmented or not) in the analysis of the factors that influence the intensity of fragmentation. From an empirical point of view, our work is based on individual data on all French industrial firms derived from the annual survey on firms and their establishments conducted by the French statistics institutes (INSEE). This data enables us to build an "organisational entropy" variable as well as the various "spatial profiles" that capture the qualitative nature (urban, peri-urban and rural) of the firm's multilocation. 
This article is structured as follows. The first section provides an overview of the literature on the organisational and spatial factors that influence firms' decisions to adopt a multi-location structure and its degree of fragmentation. The second section describes the different data bases used for this study, as well as descriptive statistics. We then present our methodology and the different variables used. The third section presents the results of the model and the conclusions.

1. The explicative factors of the different forms of organisation

A firm's decision to adopt an integrated spatial configuration (single-unit firm) or a fragmented one (multi-unit firm) raises the question of the technological, productive and managerial determinants of this choice. Multi-unit firms are also specifically confronted to the question of the location of their different units. These firms' choices are multiple and interdependent whereas the choices a single-unit firm needs to make are not. In this section, we propose a review of the economic literature that deals with the determinants of firms' behaviour in terms of their adoption of a single or multi-unit form, and, in terms of the nature and intensity of their fragmentation. Despite the increasing number of studies in international economics dealing with the question of multi-national firms, the theoretical literature in the economics of organisations remains essentially centred on single-unit firms. Few are the studies that have focused on multi-unit firms in a national context. In parallel to this, the empirical literature, which rests essentially on economic history, is generally based on monographic approaches or on samples of large firms. These approaches do not take into 
account the fact that this form of organisation is also widespread among small and medium sized enterprises (KIM, 1999).

In this context, the literature has identified two main sets of factors that might explain the existence of Multi-Unit Firms (MUFs): the firm's internal characteristics and the influence of various aspects of its environment (spatial, sectoral and commercial). However, these two dimensions are not independent and, as for all organisations, the very existence of MUFs depends on their ability to reach a coherent combination of the two. Nevertheless, the diversity of possible spatial configurations makes this articulation far more complex for this type of organisation. Thus, the first section aims to present the firms' internal characteristics that are considered in literature as factors influencing the decision to adopt a multi-unit structure. The second section deals with the influence of the firm's spatial, sectoral and commercial environments.

\subsection{The firm's internal characteristics}

All firms have internal characteristics that influence both their choice of organisational structure and the intensity of their organisational fragmentation. As CHANDLER (1990) have highlighted, economies of scale and economies of scope have a strong influence on the form of organisation adopted by firms. MARKUSEN (1995) also noted that the economies of scale obtained at the level of the production unit must be distinguished from those obtained at the level of the organisation as a whole. The first type of economies is believed to be conducive to a concentration of the means of production, favourable to a single-unit organisational structure. The influence of the second type of factors is more subtle. On the one hand, the 
spatial dispersion of activities increases managerial constraints (coordination, transport, etc.), on the other, it fosters collective learning and flexibility.

\subsubsection{Economies of scale}

Whether or not an establishment belongs to a MUF, it can potentially benefit from economies of scale. The difference between a single and a multi-unit firm then lies in the fact that the MUFs can benefit from two types of economies of scale according to whether one considers the size of the enterprise as a whole or that of its units.

At unit level, the search for economies of scale is related to the existence of increasing returns and productivity gains of a technical nature resulting from the concentration of production on one site. These economies depend on the product and on the sector of activity, the hypothesis being that a firm tends to remain integrated until it reaches its sector's average level of technical concentration or the "minimum efficiency size" (CHANDLER, 1992) that will enable the firm to produce at a lower cost. Economies of scale are found both at the level of the firm for the single-unit enterprise and at the level of the units when the organisation is a MUF.

Hyp. 1: The existence of technical economies of scale tends to act against both the adoption of a multi-unit form and a high intensity of the latter.

As for the size of the firm, it essentially has an effect in terms of economies (vs diseconomies) of scope which impact differently the two stages of the adoption decision-making process. 
With regard to the choice of organisational form, a firm's growing size might generate economies of scale, but it also generates informational problems that increase with the size of the system and the volume of information that needs to be shared. The dis-integration or fragmentation of an integrated firm into different units, that are coordinated and linked to one single-making centre, reduces the amount of information processed by each unit of the firm. These latter are then more easily manageable. The literature in organisational economics has often highlighted the role of information diffusion management in the architecture of organisations. It highlights the advantages and efficiency of organisational forms that articulate modes of organisation of production and of information exchanges between decentralized units (AOKI, 2001; WILLIAMSON, 1985). In the case of a diversified firm, this fragmentation often refers to the constitution of different profit centres and to a process of specialisation of the production sites (WILLIAMSON, 1985; KEATS and HITT, 1988).

Hyp. 2: An increase in the size of a firm, which generates information overload, is conducive to the adoption of a multi-unit organisation and to a high degree of fragmentation.

Concerning the degree of fragmentation, the right balance must be found between the necessity to segment the growing enterprise and the coordination costs associated with the existence of several new decision making centres and the diversification of activities. Fulfilling these coordination related needs is all the more crucial as it enables MUFs to manage high volumes of goods and services and thus benefit from economies of scale and scope. These increasing needs in terms of coordination often translate into the expansion of the size of the head-offices as well as of the middle management centres (CHANDLER, 1990; KIM, 1999) or into an increase in the use of information and communication technologies (HWANG, 1998; GALLIANO and ROUX, 2008). Incidentally, KIM (1999) has highlighted 
the growing relation, in American MUFs, between the number of employees working at the head-offices and the size, number of units and degree of diversification of MUFs.

\subsubsection{Economies of scope}

In parallel to this, the economies of scope achieved by a multi-unit firm can have several sources. Some authors underline the ability of MUFs to distribute the fixed costs related to specific activities such as marketing and R\&D over larger volumes of products and over a greater number of production units (MARKUSEN, 1984; KIM, 1999). According to KIM (2001), MUFs are relatively more efficient than single-unit firms thanks to their advertising and brand building strategy. It enables them to solve the problems of informational asymmetry resulting from the growing segmentation of the markets and the specialisation of the units. The creation of a brand image then significantly contributes to ensuring organisational coherence and to building a corporate identity. Furthermore, the resolution of collective coordination problems and experience sharing between the units yield an experience effect and promote organisational learning, which reinforces the MUF's efficiency (AUDIA et al., 2001). The development of a MUF implies the parallel development of individual tools of coordination, i.e. those used to facilitate inter-personal coordination (ICTs, etc.), and of more collective tools (brand image, corporate image, etc.). Thus, several studies have emphasized that the decrease of communication costs positively affects firm' decision to adopt a fragmented spatial organisation (OTA and FUJITA, 1993; FUJITA and GOKAN, 2005). These elements could be summarised in two hypotheses: 
Hyp. 3: The intensity of the firm's fragmentation depends on two considerations related to economies of scope:

- A multi-unit firm generates high coordination needs, and therefore high coordination and management costs, which has a negative effect in terms of efficiency and favours an increasing use of ICTs.

- The multi-unit organisation generates economies of scope, and in particular has the ability to distribute more effectively the fixed costs related to specific activities (R\&D, marketing, corporate image, etc.).

\subsection{Multi-location and the firm's environment}

As we have previously seen, the decision to divide a firm into different units depends on internal, technological, productive and managerial determinants. But it also specifically raises the question of the influence of the different characteristics of the firm's environment on its behaviour and mode of organisation. The following two sections are dedicated to the study of these factors. The first section deals with the spatial environment and the spatial organisation of the multi-unit firm, while the second addresses the question of its commercial and sectoral environments.

1.2.1 The spatial environment: the role of the spatial profiles of firms in organisational entropy

When a firm decides on the type of organisation it should adopt, it first has to choose between the geographical concentration of its means of production or their spatial dispersion. This 
decision not only refers to the technico-industrial choices discussed above, but also to a choice of spatial organisation. The task at hand is, first of all, to analyse the spatial factors that influence the decision to adopt a single or multi-unit organisation, and secondly, to identify in the case of MUFs, the spatial profiles that influence the intensity of organisational fragmentation.

In fact, explaining the spatial profile of MUFs requires that two levels of analysis be taken into account: the firm's head-office and the unit. The head-office of the firm centralizes and estimates the performance of its various units. It is at the head-office's level that are made the strategic, industrial, commercial, and even the financial decisions if the firm does not belong to a group. The plants generally constitute the basic productive units of the firm, where production takes place and technical economies of scale are generated. Constructing the spatial profiles of firms makes it possible to take into consideration the organisation of the MUF as a whole (its head-office and its units) and to analyse the spatial combination of their different locations, captured here at national level, by the urban, peri-urban or rural nature of each location. In the case of single unit firms, this entity is integrated in one single location.

Thus, if the integrated firm enjoys advantages in terms of economies of scale and management costs, the multi-unit firm enjoys advantages in terms of multi-location choices. Thus, it may be beneficial to locate the head-office and the production units in different types of areas that have their own specificities. A first step has been highlighted by OTA and FUJITA (1993) who show that the decrease of internal communication costs - through ICT development - leads firms to adopt a spatially fragmented organisational form. It enable firms to minimize the costs associated with an integrated urban site (rent, congestion, transport, etc.) thanks to the location of their front office (specialised in external communication) in a 
"central business district" and their back office, which perform the other tasks, in the "far suburbs". In the same vein, DURANTON and PUGA (2005) show, using the notion of urban hierarchies, that a high intensity of ICT use reduces remote management costs and is therefore conducive to spatial fragmentation in which the head-office is located in an dense urban area and the productive units are located in smaller towns, specialized in production activities.

Thus, with regards to the first step of the analysis (decision of fragmentation), the head-office' high probability of being located in a dense urban area is a central tendency highlighted in the theoretical literature on multi-unit firms, and confirmed by the few empirical studies conducted at national level (MOTA and BRANDAO, 2006). These effects of urban agglomeration refer to the size of the town, which conditions the intensity of the urban externalities derived, in particular, from having access to many public goods and services, to a large consumer market (market potential effect, see HEAD and MAYER, 2004), and above all to a diversified labour market composed of qualified labour, and in particular of the skills needed for the management activities of the firms (DURANTON et al., 2005). They also refer to the importance of the informational and technological externalities derived, in particular, from the process of co-location of head-offices. Though this "head-office" effect is demonstrated in the literature in urban economics, few studies have made the distinction between single and multi-unit firms and its implications. Only DURANTON and OVERMAN (2008) show that MUFs' units are no more attracted by single plant "head-offices" than by affiliated establishments from other MUFs. They just emphasize a strong tendency of establishments that belong to the same MUF to cluster. Investigating this point further would make it possible to highlight differences in behaviours and their interaction with organisational choices. 
In parallel to these urban agglomeration effects, the literature describes externalities that are derived from a spatial concentration of similar industrial activities (economies of location) (MALMBERG et al., 2000; GUIMARAES et al., 2000). In this context, the firm benefits from an environment that is favourable to its activity (proximity to suppliers, specialized services and workforce). Many empirical studies have confirmed the importance of these economies of location in the micro-economic choices of location, but many of them only concern new plants, new FDI (GUIMARAES et al., 2000; ARAUZO-CAROD et al., 2009), or new head-offices location's decision but without taking into account the overall spatial organisation of the firm. Nevertheless, the few studies that compare MUFs to single-unit firms show that the latter are more sensitive to location economies than MUFs (MOTA and BRANDAO, 2006), and even, the lack of influence of these effects on MUFs' choices of location for their head-offices. In this regard, DURANTON et al. (2005) show that the colocation of MUFs' head-offices in larger cities specialized in business services seems to be more efficient when the production plants are located in smaller and more specialized towns. However, it must be noted that the statistical significance of these effects have not, to our knowledge, been tested empirically. In fact, MUFs seek the best combination between urban externalities and economies of location when they choose their spatial organisation. Thus one can suppose that the spatial organisation of MUFs take into account the latter's need to colocate their head offices in urban areas and that economies of location are a more important factor at the level of the productive MUFs' units and in the location choices of single-unit firms. 
Hyp. 4: At the level of the organisational choice (first step):

- Hyp. 4a: An urban location increases the probability to be a head-office of a multiunit firm.

- Hyp. 4b: The head-offices of MUFs seem to be less influenced by the effects of location economies.

- Hyp. 4c: An important number of MUFs' headquarter in the neighbourhood increase the probability to be a head-office of a multi-unit firm.

In the second step of the analysis (intensity of fragmentation), the MUFs only are taken into account, and we can conduct a more in depth analysis of the spatial profiles of these firms. The purpose of constructing spatial profiles is to take into account the MUF's organisation as a whole (the head-office and the units) so as to analyse the spatial combination of the locations and their role in organisational entropy. As mentioned earlier, many studies only take into consideration the location of the firm's head office, and when the organisation as a whole is taken into account, only some of the possible spatial profiles are analysed in relation to management costs and to the land congestion and transport related costs associated with being located in an urban area.

However, the influence and diversity of the spatial externalities can have an effect at all the levels of the MUF's organisation, i.e. that of the head-office and that of the units even if the choice of location of the head-office is not neutral in this process. With regard to agglomeration externalities, being located in a low density area could have an unfavourable effect on the performances of the firm in that the firm is then located far from urban markets and also because the low density makes coordination more difficult (suppliers, services, proximity with others headquarters, etc.). Nevertheless, being located in a low density area 
also presents advantages; these advantages include the proximity of raw materials and the lower costs of land and of labour. In parallel to this, it may be in the interest of a rural firm to opt for a multi-location and to locate one of its units in an urban area so as to benefit from agglomeration externalities, or in peri-urban area so as to reduce its transport cost while being in proximity to consumer markets. This search for externalities of various types is one of the driving forces behind the spatial fragmentation of an organisation.

Hyp. 5: The intensity of the multi-unit structure is related to the search for diversified spatial externalities. A multi location giving the firm access to various types of externalities (urban, peri-urban and rural areas) increases the probability of a high degree of fragmentation of the firm.

\subsubsection{The commercial and sectoral environments}

The architecture of a firm is the result of organisational and spatial decisions made by its managers. However, these decisions are partly influenced by the type of commercial environment the firm is facing and by the nature of its activities. In this respect, we find variations in the rate of presence of MUFs according to their sectors of activities (see table 1). Each type of activity is associated with technical constraints and levels of technology that condition the structure of the processes of production and the corresponding division of labour. Moreover, to each sector corresponds a certain type of upstream and downstream relationships that condition their modes of productive and spatial organisation. These elements should be taken into account in the analysis as an important control variable concerning organisational choices. 
With regard to the commercial environment, the question is to know whether the market structure of the firm, and the competitive pressure it implies, influence the organisational choices. Though the literature shows the importance of the market potential in the individual choices of location (HEAD and MAYER, 2004), few studies have analysed the relationship between the fragmentation of the firm in a national context and the nature of its commercial environment. In respect to the market structure, KIM (1999) indicates that the markets in which horizontal MUFs prevail are likely to have high concentration rates, but that this does not necessarily mean that the explicit goal of these firms was to increase their market power. The relation of causality is not clear. What is more, LAMOREAUX (1983) does not find a positive relation between market concentration and the presence of horizontal MUFs. AUDIA et al. (2001) also note that the MUFs' structures, and notably their degree of fragmentation, vary according to whether their activities are aimed at local markets (hotels, banks, etc.) or at national markets. Furthermore, at the level of international markets, the literature shows that when choosing between export and FDI, a firm chooses multi-location if the economies of scale are low and/or if international trade costs are high (customs duty, transport costs, etc.). For a national firm, a high rate of export, i.e. a high degree of openness to foreign markets, will tend to be associated with a search for price competitiveness or for range-related effects that are conducive to the emergence of economies of scale and propitious to specialisation.

Hyp. 6: The literature is not clear on the relationship between market concentration and firms' fragmentation choices. On the other hand, it shows that the "integrated" form of organisation is more conducive to a search for external competitiveness and the expected effect of the export rate on organisational entropy is therefore negative. 
Finally, each form of organisation is the result of a complex articulation between industrial and spatial considerations. The nature of the organisational form plays an important role here. CHANDLER's modern MUF - which thanks to the fact that is vertically integrated upstream (raw materials) and downstream (distribution) benefits from economies of scale and of scope - is a firm that seeks to benefit from various location externalities. As for the horizontal firm, it chooses a multi-unit structure in order, more specifically, to gain better access to different, spatially dispersed, markets. The structure of a horizontal firm implies the necessity to articulate several similar and non inter-dependent units and therefore several "independent" territories. In the case of a functional segmentation, or of a productive task division, the structure of the organisation implies that the activities are fragmented into different units and are performed in separate but inter-dependent territories; this fragmentation generates specific needs, and in particular high transaction and coordination costs (HWANG, 1998).

\section{Data and Method}

This study focuses on all French industrial firms (agro-food and manufacturing sectors) with more than 20 employees. It is based on several sources of information. Firstly, the 2001 Annual Survey of Firms (ASF) provides information about the internal characteristics of the firms (size, rates of export, location of the head-office, ICT expenditures, etc.) and of their units in the case of MUFs (location of the units, type of activity, employee number, etc.). This survey also serves as a basis for our calculation of the degree of concentration of the firms' markets. The "Financial Links" survey provides information about whether or not the firms belong to groups and the ZAUER nomenclature of the INSEE-INRA (1998) is used to distinguish three different kinds of location areas: urban centres, peri-urban and rural areas. 
This data helps us draw a first description of the main characteristics of the firms examined in this study. This first description allows us to reveal significant differences between single and multi-unit firms. The second and third sections present the methodology and variables used in the model.

\subsection{The characteristics of the population}

The data base on which this model is based provides information about almost 22,218 firms of over 20 employees. This sample is divided into 15,384 single-unit and 6,834 multi-unit firms. The MUFs are defined here as firms composed of at least two distinct units. The table below indicates the main characteristics of the population studied here.

\section{[INSERT TABLE 1]}

The table above provides some interesting comparative information about the nature and the weight of MUFs in relation to single-unit firms, among French agro-food and manufacturing firms of over 20 employees. Firstly, single-unit firms are more numerous than MUFs $(6,834$ firms and 26,934 establishments). But, as shown by the statistics on the size of firms according to their nature, MUFs are less numerous but larger. Indeed, only $15 \%$ of the singleunit firms employ more than 100 workers (40\% for MUF). We also find that MUFs have a higher probability than single-unit firms of belonging to a group whereas both types of organisations are relatively evenly distributed across sectors. With respect to the industrial profile, it appears that among French MUFs the dominant organisational form is the 
horizontal form, in which all firm's units have the same activity (77\% of all French MUFs). CHANDLER's (1990) and KIM's (1999) works underline a similar tendency among American MUFs. As for the remaining 23\%, the data analysis shows that most of those firms $(80 \%)$ are vertically integrated upstream (agriculture, extraction, etc.) and/or downstream to retail (1,009 MUFs) or to business services (218 MUFs). Only 18\% of MUFs are diversified in industrial related activities (i.e. in the same 2 digit activity code) and the conglomerate profile is almost non existent $(2 \%)^{3}$

\subsection{Methodology}

This article aims to analyse the factors that determine the existence of multi-unit firms and that influence the intensity of their organisational fragmentation. These two questions can be studied using HECKMAN's (1979) two-step estimation procedure. The latter enables us to estimate a Probit model in the first step and to compare the characteristics of single and multiunit firms. In the second step, the explained variable is the intensity of fragmentation of MUFs and this procedure is used to perform a regression for a selected category of the initial population (i.e. multi-unit firms). Moreover, the HECKMAN procedure presents the advantage of correcting for the selection bias generated during the second step, as the intensity of fragmentation of the firms is only observed for MUFs. ${ }^{4}$

More formally, the methodology we use is as follows:

$$
\operatorname{MULTI}_{i}=\beta_{0}+\beta_{1} I_{i}+\beta_{2} A_{i}+\beta_{3} C_{i}+\beta_{4} S_{i}+u_{i} \quad \text { [Probit equation] }
$$

Where $u_{i}$ is an error term and MULTI $I_{i}$ a dichotomous variable equal to 1 if the firm is a MUF and to 0 otherwise. $I_{i}, A_{i}, C_{i}$ and $S_{i}$ are vectors of regressors relative to the internal characteristics of the firm and its sectoral, commercial and spatial environments respectively. 
The second equation concerns the intensity of fragmentation of MUFs. As the dependent variable of the regression equation is only observed if $\mathrm{MULTI}_{\mathrm{i}}=1$, we have to take into account the selection bias.

$$
\text { ENTROPY }_{i}=\alpha_{0}+\alpha_{1} I_{i}+\alpha_{2} A_{i}+\alpha_{3} C_{i}+\alpha_{4} S_{i}+\alpha_{5} m_{i}+v_{i} \quad \text { [regression equation] }
$$

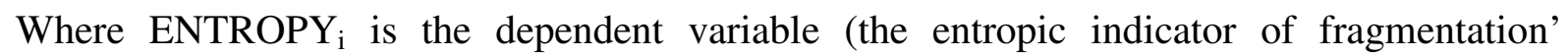
intensity). $I_{i}, A_{i}, C_{i}$ and $S_{i}$ are vectors of regressors, and $m_{i}$ is the inverse of Mills' ratio computed with the residuals of the Probit equation as follow:

$$
m_{i}=\frac{\varphi\left(\hat{\alpha} x_{i}\right)}{\Phi\left(\hat{\alpha} x_{i}\right)}
$$

Where $\varphi$ is the normal density and $\Phi$ the standard cumulative normal. The parameter estimates of $\alpha$ are obtained by augmenting the regression equation with the non-selection hazard $\mathrm{m}$ (HECKMAN, 1979). Thus, the regressors become [X m], and an additional parameter estimate $\alpha \mathrm{m}$ on the variable containing the non-selection hazard is obtained. The residuals of the augmented regression and the parameter estimate of the non-selection hazard allow us to compute a consistent estimate of the regression variance. Moreover, heteroscedasticity problems are addressed by using a WHITE matrix (1980) in all the models presented in this work.

\subsection{The variables}

In this paper, we use HECKMAN's two-step estimation procedure. In the first stage, we observe the determinants that differentiate a single from a multi-unit form of organisation. In the second stage, we concentrate on the determinants of the fragmentation intensity of the MUFs. 
For the first stage, we construct a dichotomous variable taking value 1 for MUFs and 0 otherwise (single-unit firms), which enables us to distinguish both types of organisation. In the second stage, the explanatory variable used is a measure of the degree of fragmentation of MUFs. It is an entropy index calculated at municipality level from the number of employees working in the different units of the MUF. This indicator seems to us a more relevant measure of the geographical fragmentation of MUFs than the number of their establishments, for it makes it possible to take into account the relative size of the different units of the firm. Formally, the entropy indicator is constructed as follows:

$$
\text { ENTROPY }=10^{E} \text { with } E=\sum_{r} A_{r} \log \left(1 / A_{r}\right)
$$

Where $A_{r}$ represents the share of the total workforce of the MUF that is located in zone $r$. In this paper, the scale of reference is the "commune" (or municipality). We then calculate the number of equivalent "communes" among which are dispersed the total workforce of the firm. This indicator takes value 1 if the entire workforce of the MUF is employed in the same "commune" and increases with the fragmentation of the workforce in separate plants. Thus, it enables us to study the factors that are conducive or not to a high degree of dispersion of activities in French MUFs. ${ }^{5}$

The economic literature has helped us to identify the factors that influence firms' decision concerning organisational fragmentation and the intensity of the latter. We have highlighted three types of explanatory variables relative to economies of scale and of scope, the sectoral and commercial environments of the firm, and its spatial environment. The different variables used and the calculation methods are presented in table $2 .^{6}$

[INSERT TABLE 2] 
3. The results

3.1 The general model: overall tendencies of the French industry

The general model (model 1) reveals overall tendencies concerning the French industrial sector as a whole and more precisely concerning firms of over 20 employees in the manufacturing and agro-food sectors. The model analyses, in a first step, the factors that determine the existence of multi-unit firms comparatively to that of single-unit firms, and, in the second step, the factors that influence the intensity of their organisational fragmentation. Furthermore, in order to control for the metropolitan bias, we have estimated two models, one with and one without the industrial firms located in the "Ile-de-France", i.e. Paris' region (model 2). The results of the model shows, first of all, that the correlation between both equations is significant, which justifies our choice of a HECKMAN procedure. It suggests that both stages of the MUFs' development process are inter-dependent.

\section{[INSERT TABLE 3]}

Thus, the results of model 1 highlight important differences between single and multi-unit firms in terms of internal characteristics. The effects related to the firm's size and to economies of scale are highly significant and are in keeping with the hypotheses proposed in literature. The larger the firm gets, the more likely it is to adopt a multi-unit organisational structure, and the more fragmented this structure is likely to be. The fact is that a large firm creates high organisational costs and information management problem that hinder its efficiency. It is therefore necessary for the firm to segment itself into separate units, or more 
precisely into better identified profit centres (SIMON, 1991; AOKI, 1990). The logic of economies of scale is also at play in both stages. They have a negative effect on both the adoption of a multi-unit structure and on the decision to increase the number of units. Such a decision, whether it is aimed at the specialisation of the different units or at horizontal development, must also take into account the economies of scale existing at unit level. Thus, economies of scale have a negative and significant effect on intensity. Moreover, the level of qualification of the workforce and belonging to a group of firms are also organisational characteristics that distinguish MUFs from single-unit firms. These two factors play a positive role on the decision to segment the organisation and on the degree of fragmentation. With respect to the degree of diversification, as well as the size, we note a strong relation between a high level of diversification and the intensity of fragmentation. A more in depth analysis of this relation shows that this diversification is above all vertical in nature in the case of French firms. The firms with a high degree of diversification, upstream (raw materials, agriculture...) and/or downstream (commercial, business services...), are characterised by a high level of organisational fragmentation. Let us note that this vertical structure will, logically, be favourable to an access to a diversity of spatial externalities.

In respect to the economies of scope, the results reflect the importance of collective coordination tools that are made necessary by the firm's organisational fragmentation. The first results highlight the importance of the "advertising rate" factor, which reflects the firm's identity and specificity. It has a strong effect on the first stage, i.e. on the differentiation between single and multi-unit firms. This would tend to indicate that organisational fragmentation calls for, or is facilitated by, the development of a brand image and of a corporate collective identity (KIM, 1999). This result also tends to highlight the greater efficiency of a fragmented organisation, with the creation of an urban Central Administrative 
Organisations on which the other units of the firm particularly rely for outsourcing and advertising (ONO, 2003). This factor is reinforced at collective level, by the positive and significant role of "intangible assets" variable both on the organisational choice and the intensity of fragmentation. This result refers, among other things, to the classic economies-ofscope effect on R\&D. Concerning ICT expenditures, the model does not show significant differences between single and multi-unit firms. But this variable has a positive and significant influence in the second stage of the model. In other words, MUFs do not have larger expenditures per employee than single-unit firms, but for multi-unit firms, high degrees of fragmentation imply larger ICT expenditures. This result is influenced by the high intensity of ICT use by firms located in the Paris' region.

The sectors also play a role in firms' organisational choices. The general model (model 1) shows that, in comparison with the agro-food industry, belonging to the automobile industry has a negative effect, whereas the other sectors have a positive influence on the probability to be a multi-unit firm. Let us note that this general analysis gives little information about sectors' specificities. Sector by sector estimates are provided in appendix $2 \mathrm{a}$ and $2 \mathrm{~b}$. They highlight the existence of many common influences of factors such as size, scale economies and the degree of diversification or the process of co-location of head offices on the fragmentation choice of firms. But the estimates also highlight that some internal (advertising rate and belonging to a group) and external (competitive pressure) characteristics of the firm have a varied influence from one sector to another. It is the differences in the influence of the spatial variables (firms' location and their spatial profiles) on fragmentation-related decisions that are the most marked. These results underline that each sector has different relationships to space, and in particular that agro-food firms located in rural areas tend to be more fragmented. The sectoral effects observed in the general model (model 1) do not appear to be related to the 
technological level of the sectors. We can see that MUFs are characterized by a low technological intensity in comparison with single-unit firms. Moreover, in the second step, the higher the technological level of activities the less fragmented the MUF. Finally, commercial pressure has an overall negative effect on the probability to be a MUF and also to be a highly fragmented one. Thus, a high degree of openness to foreign markets lowers a firm's probability of being dispersed. A high rate of export could indicate that the firm benefits from scale economies resulting from the specialisation of its units. ${ }^{10}$ As for the degree of concentration in the firm's main sector of activity, we observe that MUFs tend to be located on markets characterised by a low degree/level of concentration. This result does not validate the hypothesis according to which MUFs seek market power but it tends to show, in particular in the case of horizontal firms, that fragmentation presents the advantage of increasing a firm's presence and proximity to different spatially dispersed markets. The indicator of market concentration used in the model is calculated at national level. It has also been calculated at the French "région" and "département" levels and its use in the model has not led to any significant changes in the results.

In regard to the spatial environment, urbanisation economies, economies of location and colocation processes have a significant influence on the choice of organisational form. As expected, a firm whose head-office is located in an urban area is more likely to be a MUF than a single-unit firm. This indicates in particular, the importance of the influence of urban agglomeration externalities, in their commercial, technological and informational dimensions, on the location of the head-office. Indeed, the multi-unit form of organisation enables firms to benefit from urban externalities at head-office level. In particular, this type of area allows MUF to access more easily to a qualified workforce (OTA and FUJITA, 1993; HENDERSON and ONO, 2008). This fact is also illustrated by the positive and significant effect of the 
variable related to the level of qualification of employee. In parallel to this, a firm whose head-office is located in a rural or peri-urban area has a lesser probability of being a MUF. These points will be developed in the following section. As for the economies of location, they also play a positive role in the decision to adopt a fragmented form of organisation. This result needs to be examined further in order to determine which type of economies of agglomeration (urban or location) MUFs are the most sensitive to. The few studies that have been conducted on multi-unit firms tend to show that MUFs are generally more sensitive to the effects of urban agglomeration, than to the effects of location economies (MOTA and BRANDAO, 2006). Concerning the importance of economies of location, the literature places strong emphasis on the importance of the specialized cluster effects in the processes of agglomeration of firms (VICENTE and SUIRE, 2007) but does not make a distinction between the different forms of organisation.

Finally, the analysis of the composition of the firm's location area provides additional information about the processes of co-location and their role in the firm's organisational choices. Thus, we can see that MUFs' headquarters tend to be located in areas characterized by a high number of other MUFs' head-offices and few single-unit firms. Moreover, the number of productive and non productive MUFs' establishments does not significantly distinguish the location area of MUFs headquarters from that of single-unit firms. In general, we found that MUFs' units are not concentrated together. However, in the case of MUFs' head-offices, they tend to cluster.

Concerning the second step of the model, an examination of the spatial profiles of MUFs allows for an in-depth analysis of the spatial determinants of firms' behaviour in terms of the intensity of multi-location. The search for urban externalities plays a dominant role in the 
spatial organisation of French MUFs and firms with urban head-offices represent the most common form of organisation among MUFs (67.5\% of all French MUFs, see table 5). However, the results of the econometric model qualify this empirical result and reveal that the degree of organisational fragmentation is strongly related to the search for a diversity of spatial externalities. ${ }^{11}$ Thus, the MUFs whose units are all located in urban areas (i.e. $40.8 \%$ of all MUFs, see table 5) are less fragmented than other urban firms. More precisely, the most fragmented firms are those whose head-offices are located in urban areas and whose units are in both peri-urban and rural areas. This search for a diversity of spatial externalities also concerns rural and peri-urban firms: the spatial profile of a firm that has units in urban, periurban and rural areas always has a highly positive and significant effect on the degree of fragmentation. On the contrary, the profile of MUFs whose units are only located in rural areas or only in peri-urban areas has a negative effect on the degree of organisational fragmentation. The rural-urban profile also has a negative effect (non significant if we include the Paris region and significant if do not) on a firm's probability of being fragmented, This result tend to show that rural firms, which choose a fragmented spatial organisation, have the main part of their employees in rural area but have also a small part of their workers in urban area to have easy access to urban externalities. We note, finally, that the previously observed link between the degree of diversification and the degree of organisational fragmentation is also observed in relation to spatial externalities. A vertical firm is characterised by a more diversified spatial structure in terms of spatial externalities than a horizontal firm. The latter tends to look more specifically for market potential and a location in urban areas of varying sizes.

With regards to the metropolitan bias, there are few differences between the results of the model that excludes the Paris' region (model 2) and the general model (model 1). However an 
interesting result is that the wage effect has more impact on provincial firms and that the spatial effect of being located in a peri-urban area is less significant outside the Paris' region. All the other results are identical, including the results concerning the process of co-location of head-offices. Thus, this tends to show that the effects of polarization are relative and tend to confirm the structuring role of large provincial cities in the industrial dynamics of France.

\subsection{The organisational behaviour of firms according to their location}

The location-based model aims to show if the overall characteristics that differentiate MUFs and single-unit firms are observed regardless their area of location. Concerning the selection problem, we note that the three models (urban, peri-urban and rural) are affected by some selection bias, which justifies our using HECKMAN's estimation procedure.

\section{[INSERT TABLE 4]}

As table 4 indicates, certain tendencies highlighted by the general model (model 1) apply regardless of the type of area in which the head-office is located (models 3, 4 and 5). The results show, in particular, that the size of MUFs, their belonging to a group and a high level of intangible asset are always conducive to a spatial fragmentation of the organisation. Similarly, the search for economies of scale has a negative effect wherever the firm's headoffice is located. A high degree of diversification is also conducive, whatever the location of the head-office, to a high degree of multi-location. 
However, several factors differentiate multi and single-unit firms according to their location. We observe differentiated behaviours in terms of internal characteristics and of individual/collective spending. Though the rate of advertising investment has no influence on peri-urban firms, this factor differentiates positively and significantly both urban and rural MUFs from single-unit firms. This result, though classic for urban areas, is less obvious in the case of rural firms. It tends to reveal the importance of advertising - which for rural firms is generally designed to build a brand image based on a territory's character (AOC, etc.) - in the differentiation between firms and in the rural firms' search for competitiveness. This search is conducive to the implementation of a multi-unit structure, but does not influence the degree of fragmentation (negative effect with little significance). As for the peri-urban multi-unit firms, they operate according to a more productive logic, which is facilitated by the availability of a more qualified workforce and a degree of fragmentation that is more related to an increased use of ICT than to the development of a brand image. Let us note that the ICT variable does not play the role which the literature expects it to play, and has no specific role in the management of coordination needs related to organisational fragmentation, except in the case of peri-urban firms. A confirmation of these results would require a more in-depth analysis of the nature and intensity of use of these tools. Let us also note that the level of qualification does not significantly differentiate single from multi-unit firms in urban, and above all, in rural areas. These two types of areas correspond to two different labour markets: they are dense and diversified in urban areas whereas they are characterized by a low qualified workforce with a low level of mobility in rural areas. Firms, regardless of their organisational structure, adapt to these different types of market.

With respect to the sectoral determinants, the tendencies shown in the general model are also highlighted in the location-based model, with however, two effects: an urban effect of 
consumer goods on entropy, which is not observed in areas that are far from cities, and a periurban effect of the automobile industry conducive to the fragmentation of the peri-urban firms that do not operate in urban or rural areas. Moreover, the national and international market differentiates urban firms from peri-urban and rural firms. The rate of market concentration only has a negative effect on entropy in the case of urban MUFs, and has no effect in the case of peri-urban and rural firms, which are located further away from consumer areas. In parallel to this, the negative effect of the export rate on MUFs' entropy, in comparison to that of single-unit firms, is neutralized in urban areas. It probably indicates that firms that wish to export, whether they are single or multi-unit firms, choose to locate in urban areas.

With respect to the spatial environment of firms, we observe that the tendencies of the processes of co-location are confirmed. The MUFs' headquarters tend to be located in areas characterized by a high number of other MUFs' head-offices and by a low number of singleunit firms. However, the non significant effect of co-location with other plants is not confirmed in urban areas. We find a negative effect of the high density of tertiary-sector MUFs' units on the decision to be an urban MUF. Moreover, the degree of fragmentation is, as in the general model, strongly related to the search for a diversity of spatial externalities. Within each zone, the spatial profile of firms that have units in all three types of areas has a highly positive and significant effect on the degree of fragmentation. Further more, the significant effect of the economies of location tends to show that a firm's fragmentation, and the processes of co-location it implies, is also the result of a search of proximity to with similar or related activities.

The spatial organisation of the firm is also related to the industrial profile of the MUF (see table 5). The data show that a large part of the horizontal firms are "only-urban" firms: $42 \%$ 
of horizontal firms have their head-office and units only located in urban areas. In number of firms, this result tends to confirm that horizontal firms are characterised by a need to gain access to urban markets of different sizes (KIM, 2001).

\section{[INSERT TABLE 5]}

Vertical firms have a higher probability of being "multi-located": only $37.1 \%$ of them are "only urban" firms. Furthermore, vertical firms are also more representative of the triplelocation profile (urban, peri-urban and rural). This location pattern only concerns a small percentage of horizontal firms $(5.5 \%)$ against $12.8 \%$ for the vertical firms. Thus, French vertical firms have their head-offices in urban centres (68.4\%) but they are more geographically dispersed on the territory. They have their head-offices in urban areas in order to benefit from agglomeration externalities, and their other units in peri-urban, or even rural areas. These results appear to empirically confirm - and expand - the type of spatial profiles (firms with their head-offices in urban areas and units in peripheral areas) highlighted by OTA and FUJITA (1993).

\section{Conclusion}

The aim of this paper has been to analyse the mechanisms of development of multi-unit firms in the French industry. We have aimed to analyse the factors which, in the first stage of the process, influence the firm's probability of being a multi-unit organisation and, in the second stage, those that are favourable to a high degree of organisational fragmentation. From a theoretical point of view, and though the literature on MUFs in a national context is relatively scarce, several approaches proposed in the theory of organisations and international 
economics, help to better understand this type of organisation. The first section presents an overview of this literature, which highlights the influence of firms' internal characteristics and of their competitive, sectoral and spatial environments on their adoption of a multi-unit structure. The hypotheses are tested by using a HECKMAN (1979) procedure and data from the French National Survey on Industrial Firms provided by the INSEE (almost 6,800 MUFs and 15,500 single-unit firms). Beyond the general model, we seek to highlight that the logics differ according to the location of the firm's head-office (urban, peri-urban and rural).

In terms of results, both stages of the process of organisational decision reveal the importance of the firm's internal characteristics. In keeping with CHANDLER's analysis, we find that the economies of scale and of scope play a central role in organisational dynamics. Technical economies of scale clearly have a negative impact on the probability to have a multi-unit form of organisation and on the degree of fragmentation of the firm. On the contrary, larger firms are more likely to be multi-unit organisations. Furthermore, an increase in the size of the firm, which generates organisational entropy, tends to be positively correlated with the degree of fragmentation of the MUF. In terms of economies of scope, the effects we have observed are also in keeping with theoretical expectations. On the one hand, we note the existence of economies of scope (intangible assets expenditures, advertising, etc.) that characterize the multi-unit firms comparatively to single-unit ones, and on the other, we find an increasing use of individual and collective coordination tools (ICT expenditure, brand image, etc.) as a solution to the problem of high management costs generated by the increasing fragmentation of MUFs.

With regards to the spatial environment, the general model highlights two main interrelated tendencies: the influence of being located in an urban area on the existence of MUFs, but also 
the major role played by multi-location on the intensity of their fragmentation. Moreover, the organisational factors are often mobilised differently according to the location of the firm. Though the effect of intangible assets does not change, regardless of where the firm's headoffice is located, the other factors (advertising expenditures, ICT, etc.) often differentiate single and multi-unit firms. In terms of co-location patterns, the results also show that MUFs' headquarters tend to be located in areas characterized by an important number of other MUFs' head-offices as well as a low number of single-unit firms.

Overall, the results reveal the complex interactions between the spatial and industrial dynamics of the firms and the diversity of the resulting organisational structures. Multi-unit firms are not all the same and their characteristics call into question the traditional theory of location based on the single-unit firm model. This calls, not only for a close examination of the mechanisms at play in the development of MUFs, but also for an in-depth analysis of the mechanisms of multi-location and of the forms of articulation and integration of these MUFs in their local environments. These questions are all the more important in terms of territorial development policies as these firms, because of their geographical dispersion, are a central element in the analysis of the industrial specialisation of regions. The spatial fragmentation of the firm could be an interesting strategy to go beyond geographical lock-in and a path of development for rural areas. Furthermore, even if the multi-unit firm largely contributes to the processes of functional specialisation of spaces, the sectoral logics are still important as we have seen. Thus, a more in-depth analysis of sector-based approach to firms' fragmentation choices could reveal interesting variations in the influence of internal and external variables of firms on their spatial organisation choices. 
Notes:

1. For studies on multi-unit firms in a national context, one can refer to: OTA and FUJITA (1993), KIM (1999), DURANTON and PUGA (2005) or MOTA and BRANDAO (2006).

2. In this paper, the unit of analysis is the firm and not the group of firms (defined as a set of financially affiliated domestic and/or international subsidiaries). So, we only focus on the fragmentation of firms and their different plants (rather than on groups and their subsidiaries). One of the limitations of this study is the lack of information about the plants located abroad. However, the extent of this problem might be limited as indeed, very few French MUFs have plants located abroad. When French firms wish to become international they create subsidiaries rather than plants with no legal autonomy.

3. The other types of diversification correspond to the firm performing closely related industrial activities (10\%) i.e. in the same 2 digit sector, or less related activities (8\%), i.e. between 2 digit sectors. In the remainder of the article, diversified MUFs will therefore be analysed as vertical firms.

4. As we work on cross section data, we could also face endogeneity problems, in particular for variables such ICT expenditures, advertising rate or intangible assets. We address this bias through the instrumentation of these variables (using variables such as the mean wage, capitalistic intensity, added value rate, etc.), but this does not change anything to the results. 
5. The territorial unit and the method of data aggregation chosen play an important role in the analysis of firms' spatial choices and their influence on the results obtained is not neutral (see Modifiable Areal Unit Problem, BRIANT et al., 2010). In order to test the robustness of our choice (i.e. calculation of organisational entropy based on the smallest administrative territorial unit, that is the "commune" (or municipality)), we have tested our results by calculating the entropy using two other, more aggregated, administrative units: the "départements" (NUTS 3) and the "regions" (NUTS 2). The changes of geographical scale have almost no impact on the results. Only a few spatial rural profiles become non significant.

6. Descriptive statistics on the variables used in the models are presented in appendix 1.

7. In order to avoid duplicate counting, expenses in computer software (which are part of the ICT expenses and intangible assets) were removed from the intangible assets (CORRADO et al., 2006).

8. This variable only plays a role at the second stage of the Heckman type model, since by default the single-unit firms are considered as specialised in one market/product.

9. The French territory is divided into 348 "employment areas". These areas are defined as the geographical units within which most people work and live. As this spatial typology is constructed in a similar way to the English travel-to-work areas, it is this term that will be employed in the paper.

10. Beyond the economies of scale, which are more favourable to single-unit firms, this negative effect of the rate of export on the firm's probability of choosing a fragmented 
structure, can also translate the existence of productive subsidiaries abroad, which would reduce their propensity to export (arms length transactions). This effect is partly controlled for by the state of belonging to a group, but insufficiently so for we have no information about the groups' possession of subsidiaries abroad.

11. As mentioned by one of the referees, it is obvious that the more fragmented a firm, the higher the probability that the MUF has establishments located in different types of areas. To control for this effect in the second step of the models, we have tested the introduction of the number of establishments as an additional explicative variable of the fragmentation intensity and this did not make any difference to the results (these results are not presented in the article).

12. In number of firms, $75 \%$ of French industrial MUFs are composed of 2 or 3 establishments but they only account for $40 \%$ of the total MUF's workforce.

Bibliography:

AOKI M. (1990) Toward an economic model of the Japanese firm, Journal of Economic Literature 28, 1-27.

AOKI M. (2001) Towards comparative institutional analysis, MIT Press, Cambridge.

ARAUZO-CAROD J.M. and VILADECANS-MARSAL E. (2009) Industrial location at the intra-metropolitan level: the role of agglomeration economies, Regional Studies 43, 545-558. 
AUDIA P.G., SORENSON O. and HAGE J. (2001) Tradeoffs in the organization of production: multiunit firms, geographic dispersion and organizational learning, in BAUM J.A.C. and GREVE, H.R. (Eds), Multi-unit Organization and Multi-market Strategy. JAI Press.

BRIANT A., COMBES P.P. and LAFOURCADE M. (2010) Dots to boxes: do the size and shape of spatial units jeopardize economic geographic estimations ?, Journal of Urban Economics 67, 287-302.

CHANDLER A.D. (1977) The visible hand: the managerial revolution in the American business. Harvard University Press, Cambridge.

CHANDLER A.D. (1990) Scale and scope: the dynamics of industrial capitalism. Belknap, Cambridge.

CHANDLER A.D. (1992) Organizational capabilities and the economic history of the industrial enterprise, Journal of Economic Perspectives 6, 79-100.

CHEVASSUS-LOZZA E. and GALLIANO D. (2003) Local spillovers, firm organization and export behaviour: evidence from the French food industry, Regional Studies 37, 147-158.

CORRADO C., HULTEN C. and SICHEL D. (2006) Intangible capital and economic growth, Finance and Economics Discussion Series n²006-4, Federal Reserve Board. 
DICKEN P. (1976) The multi-plant business enterprise and geographical space: some issues in the study of external control and regional development, Regional Studies 10, 401-412, and Special issue of Regional Studies 41, 2007 Supplement, pp. 37-48.

DURANTON G. and OVERMAN H.G. (2008) Exploring the detailed location patterns of UK manufacturing industries using microgeographic data, Journal of Regional Science 48, 213243.

DURANTON G. and PUGA D. (2005) From sectoral to functional specialisation, Journal of Urban Economics 57, 343-370.

FUJITA M. and GOKAN T. (2005) On the evolution of the spatial economy with multi-unit multi-plant firms: the impact of IT development, Portuguese Economic Journal 4, 73-105.

GALLIANO D. and ROUX P. (2008) Organisational motives and spatial effects in Internet adoption and intensity of use: evidence from French industrial firms, Annals of Regional Sciences 42, 425-448.

GUIMARAES P., FIGUEIREDO O. and WOODWARD D. (2000) Agglomeration and the location of foreign direct investment in Portugal, Journal of Urban Economics 47, 115-135.

HEAD K. and MAYER T. (2004) Market potential and the location of Japanese investment in the European Union, The Review of Economics and Statistics 86, 959-972. 
HECKMAN J.J. (1979) Sample selection bias as a specification error, Econometrica 47, 153162.

HENDERSON J.V. and ONO Y. (2008) Where do manufacturing firms locate their headquarters ?, Journal of Urban Economics 63, 431-450.

HWANG J.S. (1998) Computer networks and the reorganization of corporate space: the case of the Korean electronics industry, Papers in Regional Science 77, 131-154.

INSEE-INRA (1998) Les campagnes et leurs villes. INSEE, Collection Contours et Caractères.

KIM S. (1999) The rise of multiunit firms in U.S. manufacturing, Explorations in Economic History 36, 360-386.

KIM S. (2001) Markets and multiunit firms from an American historical perspective, in BAUM J.A.C. and GREVE H.R. (Eds), Multiunit Organization and Multimarket Strategy. JAI Press.

KEATS B.W. and HITT M.A. (1988) A causal model of linkages among environmental dimensions, macro organizational characteristics, and performance, Academy of Management Journal 31, 570-598.

LAMOREAUX N. (1985) The great merger movement in American business, 1895-1904. Cambridge University Press, Cambridge. 
MALMBERG A., MALMBERG, B. and LUNDQUIST P. (2000) Agglomeration and firm performance: economies of scale, localisation, and urbanisation among Swedish export firms, Environment and Planning A 32, 305-321.

MARKUSEN J.R. (1984) Multinationals, multi-plant economies and the gains from trade, Journal of International Economics 16, 205-226.

MARKUSEN J.R. (1995) The boundaries of multinational enterprises and the theory of international trade, Journal of Economic Perspectives 9, 169-189.

MOTA I. and BRANDAO A. (2006) The determinants of location choice: single-plant versus multi-plant firms, paper presented at European Regional Science Association, Volos, Greece.

ONO Y. (2003) Outsourcing business services and the role of central administrative offices, Journal of Urban Economics 53, 377-395.

OTA M. and FUJITA M. (1993) Communication technologies and spatial organization of multi-unit firms in metropolitan areas, Regional Science and Urban Economics 23, 695-729.

SCOTT A.J. (1986) Industrial organization and location: division of labor, the firm, and spatial process, Economic Geography 62, 215-231.

SIMON H. (1991) Organizations and markets, Journal of Economic Perspectives 5, 25-44. 
VICENTE J. and SUIRE R. (2007) Informational cascades versus network externalities in locational choice: evidence of "ICT Clusters" formation and stability, Regional Studies 42, $173-184$.

WHITE H. (1980) A heteroskedasticity-consistent covariance matrix estimator and a direct test for heteroskedasticity, Econometrica 50, 1-25.

WILLIAMSON O.E. (1985) The economic institutions of capitalism. Free Press, New-York. 


\begin{tabular}{|c|c|c|c|c|c|c|}
\hline & \multicolumn{3}{|c|}{ Number of establishment } & \multicolumn{3}{|c|}{ Number of worker } \\
\hline & $\begin{array}{l}\text { Whole } \\
\text { firms }\end{array}$ & $\begin{array}{l}\text { Single-unit } \\
\text { firms }\end{array}$ & $\begin{array}{l}\text { Multi-unit } \\
\text { firms }\end{array}$ & $\begin{array}{l}\text { Whole } \\
\text { firms }\end{array}$ & $\begin{array}{l}\text { Single-unit } \\
\text { firms }\end{array}$ & $\begin{array}{l}\text { Multi-unit } \\
\text { firms }\end{array}$ \\
\hline Total & 22,218 & 15,384 & 6,834 & $2,833,315$ & $1,087,398$ & $1,745,917$ \\
\hline Size: & & & & & & \\
\hline - 20 to 49 employees & $57.4 \%$ & $65.9 \%$ & $38.2 \%$ & $14.8 \%$ & $30.6 \%$ & $5.1 \%$ \\
\hline - 50 to 99 employees & $19.3 \%$ & $19.4 \%$ & $19.1 \%$ & $10.6 \%$ & $19.2 \%$ & $5.3 \%$ \\
\hline - 100 to 499 employees & $19.3 \%$ & $13.8 \%$ & $31.5 \%$ & $30.7 \%$ & $36.1 \%$ & $27.5 \%$ \\
\hline - Over 500 employees & $4.0 \%$ & $0.9 \%$ & $11.2 \%$ & $43.9 \%$ & $14.1 \%$ & $62.1 \%$ \\
\hline $\begin{array}{l}\text { Belonging to a group of } \\
\text { firms }\end{array}$ & $63.7 \%$ & $58.8 \%$ & $74.7 \%$ & $87.6 \%$ & $76.3 \%$ & $94.7 \%$ \\
\hline Head office location*: & & & & & & \\
\hline - urban & $59.4 \%$ & $55.8 \%$ & $67.6 \%$ & $63.9 \%$ & $58.6 \%$ & $71.7 \%$ \\
\hline - periurban & $17.6 \%$ & $19.3 \%$ & $13.7 \%$ & $15.1 \%$ & $18.2 \%$ & $10.8 \%$ \\
\hline - rural & $23.0 \%$ & $24.9 \%$ & $18.7 \%$ & $21.0 \%$ & $23.2 \%$ & $17.5 \%$ \\
\hline $\begin{array}{l}\text { Sector of activity: } \\
\text { - Agro-food }\end{array}$ & $12.2 \%$ & $10.9 \%$ & $15.2 \%$ & $12.8 \%$ & $11.7 \%$ & $13.6 \%$ \\
\hline - Consumer goods & $20.1 \%$ & $19.3 \%$ & $21.8 \%$ & $17.8 \%$ & $17.1 \%$ & $18.2 \%$ \\
\hline - Automobile & $2.4 \%$ & $2.5 \%$ & $2.1 \%$ & $8.8 \%$ & $9.6 \%$ & $8.5 \%$ \\
\hline - Equipment goods & $21.9 \%$ & $22.8 \%$ & $19.9 \%$ & $20.1 \%$ & $20.1 \%$ & $20.1 \%$ \\
\hline - Intermediate goods & $43.4 \%$ & $44.5 \%$ & $41.0 \%$ & $40.5 \%$ & $41.5 \%$ & $39.6 \%$ \\
\hline
\end{tabular}

Table 1. Descriptive statistics according to the nature of the firm

Sources: ASF 2001 and Financial Link survey 2001.

* Only workers of headquarters are taken into account here. It doesn't change anything for single-unit firms but the workers location of MUFs' productive or non-productive establishments doesn't appear here. 
Table 2. Variables calculation method and expected effects

Economies of scale and scope

Size of the firm 4-modality qualitative variable: from 20 to 49 employees, from 50 to 99 emp., from 100 to 499 emp. and more than $500 \mathrm{emp}$

Scale economies Logarithm of the rate of the firm's size (single unit firm) or the mean establishments' size (MUFs) to the average size of units of the sector ( 3 digit).

Mean wage level Logarithm of the wage bill of the firm to the number of employees. Belonging to a group Dummy variable: yes (subsidiary ) or no (independent firm).

Advertising rate

Intangible assets

Logarithm of the ratio of the advertising expenditure of the year to the firm's turnover.

per employee (R\&D, patent, licence, etc.). ICT exp. per emp. $\quad$ Logarithm of the average ICT expenditure per employee of the year: proxy for the firm's coordination needs.

Level of

Diversification $^{8}$ -modality qualitative variable of based on an entropy index of diversification calculated from the distribution of the firm's workforce between

(index $>2$ )

Sectoral and commercial environment

Sector 5-modality qualitative variable for the main industrial sector of the firm (2 digit level).

Control var.

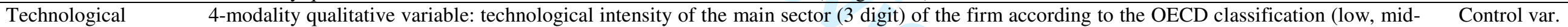

intensity low, mid-high or high technology firm).

Market concentration Herfindahl index of the market concentration calculated at the 3 digit level. The total turnover of the firm is assigned to its main market.

Export rate

Logarithm of the ratio export turnover/total turnover of the firm.

$+/+$

Spatial environment

Spatial agglomeration 3-modality qualitative variable. The urban zones are composed of contiguous "communes" that account for more than 5000 jobs. The peri-

in the area of location

urban zones are areas with a large percentage of the population of which work in urban areas. Rural areas are contiguous «communes » that account for less than 2,000 jobs, and areas that are neither urban nor peri-urban zones.

Co-location process Logarithm of the number of MUFs' headquarter, productive MUFs' unit, MUFs' non productive unit (generaly commercial and services activities) or single-unit firms in the employment area (or travel-to-work area) of location of single-unit firm or firm's headquarter for MUFs.

$+/+$

Not used/+ used

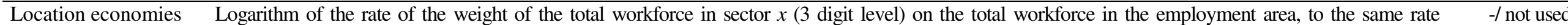
calculated for France.

Spatial organization 12-modality qualitative variable for the spatial organization of MUF according to the nature of the location' areas of the head office and its of MUFs 
Commercial determinants:

Table 3. The determinants of adoption and intensity of a multi-unit organisational structure: general model

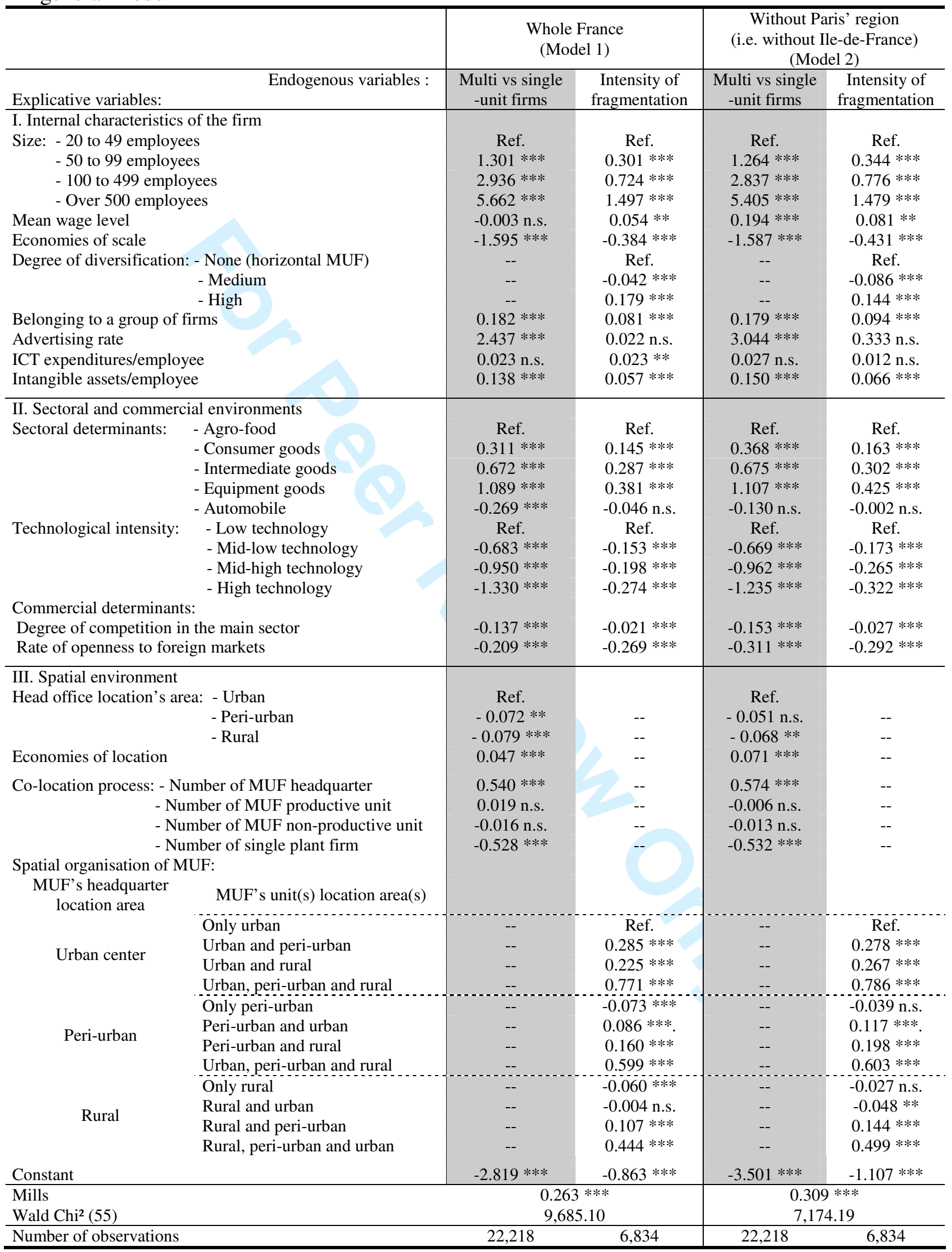

Sources: ASF 2001 and Financial Link survey 2001. *,**,*** Indicate statistically significant coefficients at the 10, 5, and $1 \%$ levels respectively, while n.s. means that the variable is non significant. 
11 I. Internal characteristics of the firm

12 Size: - 20 to 49 employees

$13-50$ to 99 employees

$14-100$ to 499 employees

15 - over 500 employees

16 Mean wage level

17 Economies of scale

34 Commercial determinants:

35 Degree of competition of the main sector

36 Rate of openness to foreign markets

III. Spatial environment

Economies of location

Co-location process: - Nb. of MUF headquarter

- Nb. of MUF productive unit

- Nb. of MUF non-prod. unit

- Nb. of single plant firm

Spatial organisation of MUF:

MUF's headquarter location

Urban center

MUF's unit(s) location Only urban

Urban and peri-urban

Urban and rural

Urban, peri-urban and rural

Only peri-urban

Peri-urban

Peri-urban and urban

Peri-urban and rural

Urban, peri-urban and rural

Only rural

Rural

Rural and urban

Rural and peri-urban

Rural, peri-urban and urban

Constant

Mills

Wald Chi ${ }^{2}$ (39)

Number of observation

Urban model
(Model 3)

\begin{tabular}{cc} 
Multi vs & $\begin{array}{c}\text { Intensity of } \\
\text { sragmente-unit } \\
\text { fration }\end{array}$ \\
\hline
\end{tabular}

Ref.

$1.40 * * *$

$3.11 * * *$

$5.98 * * *$

-0.08 n.s.

$-1.67 * * *$

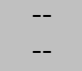

$--$

$0.20 * * *$

$2.85 * * *$

0.01 n.s.

$0.13 * * *$

\section{Ref.}

$0.30 * * *$

$0.73 * * *$

$1.50 * * *$

$0.05 * *$

$-0.37 * * *$

Ref.

-0.01 n.s.

$0.20 * * *$

$0.07 * * *$

0.16 n.s.

0.02 n.s.

$0.05 * * *$

Ref.

$0.34 * * *$

$0.68 * * *$

$1.13 * * *$

$-0.26 * *$

Ref.

$-0.73 * * *$

$-1.01 * * *$

$-1.42 * * *$

$-0.16 * * *$

-0.09 n.s.

\section{Ref.}

$0.19 * * *$

$0.31 * * *$

$0.39 * * *$

-0.06 n.s.

Ref.

$-0.13 * * *$

$-0.15 * * *$

$-0.24 * * *$

$-0.03 * * *$

$-0.27 * * *$

$0.04 * * *$

$0.54 * * *$

0.08 n.s.

$-0.05 *$

$-0.54 * * *$

of a multi-unit organisational structure:

Sources: ASF 2001 and Financial Link survey 2001.*******

$1 \%$ levels respectively, while n.s. means that the variable is non significant. 
Table 5. Spatial profiles, degree of diversification of MUFs and mean number of units.

\begin{tabular}{clcccc}
\hline $\begin{array}{c}\text { MUF's } \\
\text { headquarter } \\
\text { location's area }\end{array}$ & \multicolumn{1}{c}{$\begin{array}{c}\text { MUF's unit(s) } \\
\text { location's area(s) }\end{array}$} & $\begin{array}{c}\text { Whole } \\
\text { MUFs }\end{array}$ & $\begin{array}{c}\text { Horizontal } \\
\text { MUFs }\end{array}$ & $\begin{array}{c}\text { Vertical } \\
\text { MUFs }\end{array}$ & $\begin{array}{c}\text { Mean } \\
\text { number of } \\
\text { units }\end{array}$ \\
\hline \multirow{3}{*}{ Urban } & Only urban & $40.8 \%$ & $41.9 \%$ & $37.1 \%$ & 3.11 \\
& Urban and peri-urban & $10.4 \%$ & $11.4 \%$ & $13.0 \%$ & 5.58 \\
& Urban and rural & $11.8 \%$ & $10.6 \%$ & $9.9 \%$ & 4.43 \\
& Urban, peri-urban and rural & $4.5 \%$ & $3.4 \%$ & $8.4 \%$ & 11.45 \\
\cline { 2 - 5 } Peri-urban & Only peri-urban & $3.3 \%$ & $3.5 \%$ & $2.3 \%$ & 2.18 \\
& Peri-urban and urban & $7.3 \%$ & $7.5 \%$ & $6.5 \%$ & 3.03 \\
& Peri-urban and rural & $2.0 \%$ & $2.2 \%$ & $1.2 \%$ & 2.45 \\
& Peri-urban, urban et rural & $1.3 \%$ & $1.0 \%$ & $2.3 \%$ & 10.29 \\
\cline { 2 - 5 } Rural & Only rural & $7.0 \%$ & $7.6 \%$ & $4.9 \%$ & 2.31 \\
& Rural and urban & $8.2 \%$ & $7.5 \%$ & $10.3 \%$ & 3.22 \\
& Rural and peri-urban & $2.1 \%$ & $2.3 \%$ & $2.0 \%$ & 2.74 \\
& Rural, urban and peri-urban & $1.3 \%$ & $1.1 \%$ & $2.1 \%$ & 5.91 \\
\cline { 2 - 6 } & Total & $100 \%$ & $100 \%$ & $100 \%$ & 3.94 \\
& Number of firms & 6,831 & 5,261 & 1,570 & 6,831 \\
\hline
\end{tabular}

Sources: ASF 2001. 
Appendix 1. Descriptive statistics of the variables

\begin{tabular}{lcccccc}
\hline Variable & Mean & $\begin{array}{c}\text { Standard } \\
\text { deviation }\end{array}$ & Minimum & Median & Maximum & $\begin{array}{c}\text { Number of } \\
\text { observation }\end{array}$ \\
\hline Multi-unit firm & 0.308 & 0.46 & 0 & 0 & 1 & 22,218 \\
Organisational entropy & 1.37 & 1.70 & 1 & 1 & 82.9 & 22,218 \\
\hline Size & 128.1 & 464.6 & 20 & 45 & 25.900 & 22,218 \\
Mean wage level (€/h) & 24.31 & 8.58 & 7.53 & 22.95 & 168.87 & 22,218 \\
Scale economies & 1.0 & 1.25 & 0.01 & 0.65 & 32.8 & 22,218 \\
Group & 0.64 & 0.48 & 0 & 1 & 1 & 22,218 \\
ICT expenditures per & 648 & 1,830 & 0 & 219 & 101.120 & 22,218 \\
employee (€) & 0.01 & 0.03 & 0 & 0.002 & 0.5 & 22,218 \\
Advertising rate (\%) & 5.12 & 27.33 & 0 & 1.06 & 1.590 .7 & 22,218 \\
Intangible assets per & & & & & & \\
employee & 0.033 & 0.044 & 0.002 & 0.019 & 0.83 & 22,218 \\
Market competition & 0.16 & 0.23 & 0 & 0.043 & 1 & 22,218 \\
Export rate (\%) & 4.6 & 13.2 & 0.002 & 1.66 & 40.8 & 22,218 \\
Industrial specialization & & & & & & \\
\hline
\end{tabular}

Sources: ASF 2001 and Financial Link survey 2001. 
8 Explicative variables:

Appendix 2a. First steps results by sector (fragmentation choice)

9 I. Internal characteristics of the firm

10 Size: - 20 to 49 employees

- 100 to 499 employees

- Over 500 employees

Mean wage level

Economies of scale

Belonging to a group

Advertising rate

ICT expenditures/employee

Intangible assets/employee

II. Sectoral and commercial environment Sector:

Commercial determinants:

Degree of competition in the main sector

Rate of openness to foreign markets

III. Spatial environment

Head office location's area: - Urban

Economies of location

Co-location process:

- number of MUF headquarter

- nb. of MUF productive unit

- nb. of MUF non-prod. unit

- nb. of single plant firm

\section{Constant}

Mills

Wald $\mathrm{Chi}^{2}$

Number of observations
- Peri-urban

- Rural

- Consumer goods

Automobile

technology

Mid-high technology

-High technology

$\quad 22,218$ significant coefficients at the 10,5 , and $1 \%$ levels respectively, while n.s. means that the variable is non significant. 
Appendix 2b. Second step results by sector (intensity of fragmentation)

5

7 Explicative variables:

8 I. Internal characteristics of the firm

9 Size: - 20 to 49 employees

$10-50$ to 99 employees

11

12

- 100 to 499 employees

- Over 500 employees

13 Mean wage level

14 Economies of scale

15 Degree of diversification: - None (horizontal MUF)

16

17

18

19

19

20

21

22

23

55 Constant 56 Number of observations
- Medium

- High
Belonging to a group of firms

Advertising rate

CT expenditures/employee

I. Characteristics of the environment

Sectoral:

\section{- Agro-food}

- Consumer goods

- Intermediate goods

- Equipment goods

- Automobile
Technological intensity:

- Low technology

- Mid-low technology

- Mid-high technology

- High technology

Commercial determinants:

Degree of competition in the main sector

Rate of openness to foreign markets

58

\begin{tabular}{|c|c|c|c|c|c|}
\hline Whole sector & $\begin{array}{c}\text { Agri- } \\
\text { business }\end{array}$ & $\begin{array}{c}\text { Consumer } \\
\text { goods }\end{array}$ & Automobile & $\begin{array}{c}\text { Equipmen } \\
\mathrm{t} \text { goods }\end{array}$ & $\begin{array}{c}\text { Intermediate } \\
\text { goods }\end{array}$ \\
\hline Ref. & Ref. & Ref. & Ref. & Ref. & Ref. \\
\hline $0.301 * * *$ & $0.278 * * *$ & $0.301 * * *$ & 0.029 n.s. & $0.497 * * *$ & $0.153 * * *$ \\
\hline $0.724 * * *$ & $0.609 * * *$ & $0.795 * * *$ & -0.050 n.s. & $1.074 * * *$ & $0.460 * * *$ \\
\hline $1.497 * * *$ & $1.238 * * *$ & $1.597 * * *$ & $0.581 * *$ & $2.139 * * *$ & $1.016 * * *$ \\
\hline $0.054 * *$ & 0.074 n.s. & $-0.084 * * *$ & -0.032 n.s. & $0.117 * * *$ & $0.075 * *$ \\
\hline$-0.384 * * *$ & $-0.283 * * *$ & $-0.435 * * *$ & $-0.117 * *$ & $-0.550 * * *$ & $-0.245 * * *$ \\
\hline Ref. & Ref. & Ref. & Ref. & Ref. & Ref. \\
\hline$-0.041 * * *$ & $-0.133 * * *$ & -0.022 n.s. & 0.100 n.s. & -0.012 n.s. & 0.025 n.s. \\
\hline $0.179 * * *$ & $0.196 * * *$ & $0.237 * * *$ & $0.307 * * *$ & $0.107 * * *$ & $0.167 * * *$ \\
\hline $0.081 * * *$ & 0.044 n.s. & $0.073 * * *$ & 0.113 n.s. & $0.067 * *$ & $0.084 * * *$ \\
\hline $\begin{array}{c}0.022 \text { n.s. } \\
0.023 * *\end{array}$ & $\begin{array}{c}-0.095 \text { n.s. } \\
0.049 \text { n.s. }\end{array}$ & $\begin{array}{l}0.156 \text { n.s. } \\
-0.008 \text { n.s. }\end{array}$ & $\begin{array}{l}0.118 \text { n.s. } \\
0.055 \text { n.s. }\end{array}$ & $\begin{array}{l}-0.575 \text { n.s. } \\
-0.012 \text { n.s. }\end{array}$ & $\begin{array}{c}-0.757 \text { n.s. } \\
0.038 * *\end{array}$ \\
\hline $0.057 * * *$ & $0.031 * * *$ & $0.035 * * *$ & -0.025 n.s. & $0.020 *$ & $0.077 * * *$ \\
\hline Ref. & Ref. & Ref. & Ref. & Ref. & Ref. \\
\hline $0.145 * * *$ & -- & -- & -- & -- & -- \\
\hline $0.287 * * *$ & -- & -- & - & -- & -- \\
\hline $0.381 * * *$ & -- & -- & -- & -- & -- \\
\hline-0.046 n.s. & - & - & - & - & - \\
\hline Ref. & -- & - & -- & -- & - \\
\hline$-0.153 * * *$ & -- & -- & -- & -- & - \\
\hline$-0.198 * * *$ & -- & -- & -- & -- & -- \\
\hline$-0.274 * * *$ & -- & -- & - & -- & -- \\
\hline$-0.021 * * *$ & $0.058 * * *$ & $-0.073 * * *$ & $-0.152 * * *$ & $-0.124 * * *$ & -0.005 n.s. \\
\hline$-0.269 * * *$ & $-0.114 *$ & $-0.082 *$ & -0.053 n.s. & $-0.406 * * *$ & $-0.333 * * *$ \\
\hline Ref. & Ref. & Ref. & Ref. & Ref. & Ref. \\
\hline $0.285 * * *$ & $0.197 * * *$ & $0.314 * * *$ & $0.384 * * *$ & $0.238 * * *$ & $0.305 * * *$ \\
\hline $0.225 * * *$ & $0.191 * * *$ & $0.247 * * *$ & 0.052 n.s. & $0.234 * * *$ & $0.261 * * *$ \\
\hline $0.771 * * *$ & $0.656 * * *$ & $0.567 * * *$ & $0.634 * * *$ & $0.526 * * *$ & $0.954 * * *$ \\
\hline$-0.073 * * *$ & 0.022 n.s. & $-0.179 * *$ & $-0.230 *$ & -0.044 n.s. & $-0.093 * *$ \\
\hline $0.086 * * *$ & $0.170 * * *$ & 0.004 n.s.. & $0.452 * * *$. & $0.081 * *$ & $0.086 * * *$. \\
\hline $0.160 * * *$ & $0.158 * * *$ & 0.049 n.s. & 0.228 n.s. & 0.127 n.s. & $0.210 * * *$ \\
\hline $0.599 * * *$ & $0.287 * * *$ & $0.295 *$ & -0.327 n.s. & $0.598 * * *$ & $0.858 * * *$ \\
\hline$-0.060 * * *$ & 0.019 n.s. & $-0.129 * * *$ & 0.136 n.s. & -0.077 n.s. & -0.043 n.s. \\
\hline-0.004 n.s. & $0.107 * * *$ & 0.001 n.s. & 0.092 n.s. & -0.014 n.s. & -0.003 n.s. \\
\hline $0.107 * * *$ & 0.057 n.s. & 0.019 n.s. & 0.212 n.s. & 0.112 n.s. & $0.201 * * *$ \\
\hline $0.444 * * *$ & $0.344 * * *$ & 0.205 n.s. & 0.285 n.s. & 0.187 n.s. & $0.641 * * *$ \\
\hline$-0.863 * * *$ & $-0.326 * * *$ & $-0.573 * * *$ & $-0.570 *$ & $-1.477 * * *$ & $-0.466 * * *$ \\
\hline 6,834 & 1,040 & 1,492 & 143 & 1,361 & 2,798 \\
\hline
\end{tabular}

Sources: ASF 2001 and Financial Link survey 2001. *,**,*** Indicate statistically significant coefficients at the 10,5 , and $1 \%$ levels respectively, while n.s. means that the variable is non significant. 